Timothy Waligore

\title{
Comment on Véronique Zanetti. On Moral Compromise
}

\section{Introduction}

The central topic of Véronique Zanetti's article is moral compromise. As I understand Zanetti, a compromise could only be called a 'moral compromise' if (i) it does not originate under coercive conditions, (ii) it involves conflict whose subject matter is moral, and (iii) "the parties support the solution found for what they take to be moral reasons rather than strategic interests". ${ }^{1}$

A moral compromise differs from an 'offensive strategic compromise', under which the parties have no principled commitment to the compromise, but adopt it for merely strategic reasons. They are willing to go on the offensive and adjust it if more favorable conditions obtain. This is what John Rawls calls a modus vivendi.

As Zanetti explains it, a compromise is different than a consensus, where parties see the resolution as their first best option. In a compromise, the parties negotiate (or a decision is reached on) a resolution that is seen as acceptable, but not optimal, for each party. The parties modify their principle of action or their objective in the face of their continuing disagreement (426).

A moral compromise can be seen as midway between consensus and a strategic compromise (426-7). With a moral compromise, the parties do not come to have consensus on their first best views. For Zanetti, a moral compromise is not a full consensus because the parties continue to disagree on the content of the moral matters they take to be important.

There are two main contentions by Zanetti that I wish to challenge in this comment. First, John Rawls speaks of the parties having an 'overlapping consensus' that includes a shared standard of justice. Zanetti finds this to be an idealisation of what occurs, in a negative sense, since it assumes too much consensus and leaves out real world conflict. In contrast to Rawls, Zanetti contends that we seek consensus on one aim (social peace) but moral compromise on at least two other matters (the substantive content of norms and the decisiontaking procedure by which we reach this substantive content) (424). Second,

\footnotetext{
${ }^{1}$ I combine the conditions on pages 426 and 428 of Zanetti 2011.
} 
Zanetti illustrates her views on moral compromise by returning often to the example of German abortion law: "The classic example of a genuine moral compromise is first-trimester abortion. Contemporary German jurisdiction provides women with the possibility to have an 'illegal though punishment-exempt' abortion within the first three months of pregnancy." (427)

In the sections below, I offer three criticisms of Zanetti. First, Zanetti ignores how some parties may not have reason to seek social peace at all. Zanetti's claim that there is consensus on the aim of social peace can involve idealising away from disagreement in a manner that Zanetti accuses Rawls of. Second, even if there is consensus on the aim of seeking social peace, this leaves open the possibility of disagreement about which society different people should belong to. This idealises away from real world conflict concerning borders. Indeed, Zanetti does not mention that her 'central example' of moral disagreement, the German abortion compromise, was enacted in the wake of German reunification. Third, there are at least two things that can be called the 'German abortion compromise'. The compromise that Zanetti speaks of was imposed by the German Federal Constitutional Court. The court declared unconstitutional a law passed in 1992 that had been negotiated in parliament. Zanetti does not dwell on this lack of democratic credentials. Even the substance of the court-imposed solution is itself a dubious example of a moral compromise between parties based on what is acceptable to their reason.

\section{2.}

Zanetti claims that consensus on social peace is something the parties all seek, in that all parties desire to exist under a social order of norms. In this section, I ask: does this consensus only arise if we leave out disagreement by certain parties who do not favor instituting a social order of norms?

Zanetti discusses moral contractualism, which ideally demands that all norms must be justified according to the interests of all those relevantly affected. The question of the metanorm for legitimating individual norms must itself be procedurally decided, and must emerge from a contract (430). Zanetti says that the criterion of the justification of norms ideally refers to unanimity, but in nonideal conditions this may not be what the parties desire (430).

Zanetti invokes Peter Stemmer's account here, who says: "A society of people must desire this norm, and bring it into existence." (Stemmer 2004, quoted in Zanetti 2011, 430) Zanetti adds: "In other words, a society of people should decide if the requirement of legitimacy which it seeks should be the highest (everyone should agree reasonably to the norms) or should be at a lower level (the norms should be in the interest of the majority)." (430) Stemmer says that residents in the state of nature would realize that if they subjected each individual norm to a unanimity requirement, then the following problem arises: if some individuals would rather kill than be protected from killing (or would rather rape than be protected from rape), then it is not in their interest to assent to the norm. These are among the most urgent rules that need to be 
justifed and enacted for a stable social order (Stemmer 2004, 491). If each norm is individually subject to a unanimity requirement, then these urgent norms remain unjustifiable. Zanetti indicates that this result "could not be desireable to anyone" (430).

This account leaves me puzzled. I understand why those individuals, who prefer protection from injury to being able to injure others, would not want other individuals, who preferred to remain free to injure others even if they remained unprotected from injury, to be able to veto such norms. Those desiring a stable social order, if they were to reason about it, would desire a non-unanimity requirement. While some of these assenters would want a majority veto requirement, others may want a super-majority veto requirement. And a compromise must be reached among these parties. So in this sense I understand what Zanetti means when speaking about compromise on procedure.

Zanetti's argument established that all who desire social order should desire that individual norms not be assessed by a unanimity rule. Zanetti does not consider what to do when not all desire to live under a social order. She seems to simply assume all have this desire. However, some may prefer not to be subject to a system of morality. ${ }^{2}$ Why will these dissenters desire a procedure which revokes the unanimity requirement, when the purpose of compromising was for the aim of social order?

Further, if the legitimacy of the metanorm arises from the desire of people, how can the majority bind the minority here? Zanetti and Stemmer problematically speak of society as if it pre-existed the contract. For Locke (1988, II: 96), the community only has the power to decide as a body by majority, if and once the community is first formed through the unanimous consent of all individuals. For Locke, there needs to be unanimous agreement to form a society in which the majority binds the minority. Further, since Zanetti thinks that even the metanorm must emerge from a contract, I do not see how Zanetti would endorse a pre-contractual natural duty to form a society with one's neighbors or those with whom one cooperates. ${ }^{3}$

Zanetti is idealising away disagreement when she speaks of consensus on social peace. Zanetti is sensitive to disagreement about substantive norms of justice and metanorms about how to justify these substantive norms; why is it justified to leave this other sort of disagreement aside?

\section{3.}

Second, even granting that every individual seeks social peace, there is the further question of with whom they seek social peace. What if there is consensus on the principle of social peace (that everyone should belong to some political

2 Stemmer 2004, 495f., considers this possibility, and says it can be justified to impose norms on the dissenters.

${ }^{3}$ On such a natural duty, see Waldron 1996. Stemmer 2004, 489, says the contractualist knows no natural rights or duties. 
order) but not consensus on social unity (that these people should belong to this or that particular society)?

Zanetti's story relies on the assumption that all would or should agree to be part of a social order. However, Zanetti seems to silently presuppose a further consensus not simply on 'social peace' but also a consensus on 'social unity' (the desire to live together in this particular society). Any account of how a political society comes to legitimately impose norms is going to face this 'particularity requirement': why is it that this particular political society can impose these norms for a particular party? ${ }^{4}$

Zanetti criticizes Rawls' idealisation of actors as not matching the real world. Zanetti says that Rawls achieves an overlapping consensus on justice only by leaving out the 'unreasonable' parties who desist from such a consensus on the sense of justice (432). This seems a sensible criticism, as Rawls excludes much real world conflict. But the same criticism applies to Zanetti's apparent assumption about consensus about which state we belong to (which is implicit in the idea that we have consensus about social peace). Issues like this are central to current debates in political obligation, secession, and territorial rights, issues that cause much conflict in today's worlds. My point is not that we never have consensus on the end of social peace, but that Zanetti, like Rawls, may call it consensus by leaving out those who are not part of the consensus. By her own criteria for criticizing Rawls, this can be idealising theory, in a negative sense.

It might be objected that a concern for boundaries and social unity is marginal to the types of cases that Zanetti discusses. However, what she calls her "central example" of moral compromise, the German abortion compromise, arose in the wake of the process of German reunification in 1990. Such differences almost held up the unification treaty. Consensus or disagreement about social unity, rather than simply social peace, played a key role here.

At the time of reunification, West Germans in the Federal Republic of Germany faced much stricter regulations on abortion than did East Germans. East Germans in the German Democratic Republic had the right to abortion on demand in the first trimester. In 1974 in West Germany, the Social Democrats pushed through parliament an act to liberalize abortion law in the Federal Republic of Germany. Under the 1974 Reform Act, abortion would have been legal in the first trimester if women consulted a counseling service (Werner 1996, 582). However, in 1975 the Federal Constitutional Court in Germany declared the law unconstitutional and void. The Court invoked an objective hierarchy of value to declare the state must protect unborn life. Under the 1976 law passed in accord with this decision, West Germans were allowed to have an abortion only if doctors determined that one of four situations (or 'indications') were present $(584) .^{5}$

${ }^{4}$ I take the phrase "particularity requirement" from Simmons 2001, 68. See also Stilz 2009,6 .

${ }^{5}$ The indications were (1) the life of the mother was at stake, (2) the presence of genetic deformities, (3) a pregnancy had resulted from a criminal act like rape or incest, (4) and where the stress on the mother would be so severe that it would unreasonable to expect her to have the child (Werner 1996). This 'social indication' would be commonly invoked, but 
Differences on abortion almost held up the treaty on reunification, with negotiations lasting until the day the treaty was signed. It was agreed that the East and the West would temporarily keep their laws after reunification until the parliament could make a new law for all of Germany (589-590).

East German women were used to viewing abortion on demand as a right, and East German feminists were not keen to simply adopt West German laws on the subject (as happened in most other areas) (Ferree/Maleck-Lewy 2000, 100). While it may not be plausible to think of an individual who does not care about social peace at all, it is plausible to think of an East German feminist who would have preferred living under a more liberal abortion law in an independent East Germany to living under a stricter abortion law in a unified Germany.

By assuming a consensus on social unity rather than social peace, Zanetti idealises away from such conflicts, and the limits of the consensus. Any compromise (moral or non-moral) in Germany on abortion was likely not simply for social peace, but also for the goal of social unity (in the sense of a social peace within a unified Germany, rather than West Germans seeking social peace in West Germany and East Germans in East Germany).

\section{4.}

In this section, I question whether Zanetti's central example of moral compromise, the German abortion case, is indeed an instance of moral compromise, in the sense of it being grounded in part out of respect for what others will accept. To show this, I need to explain some background left unexamined by Zanetti.

After unification, parliament passed the Pregnant Women's and Families' Aid Act in June 1992. This was to apply to all of Germany. It was less conservative than the old law in West Germany but not as liberal as the law had been in East Germany. This Act arose from the 'Group Proposal' developed by women politicians, and supported by for the Social Democrats, the Free Democrats, some Western Christian Democrats, and many of the Christian Democrats from East Germany (Ferree/Maleck-Lewy 2000, 99-100). Such a coalition was possible because party discipline was not in effect on this issue (Werner 1996, 590-591). Abortion in the first trimester was declared not illegal (" nicht rechtswidrig") (593), provided women went to counselors who made sure they had adequately deliberated. Ultimately the choice would be up to the women, unlike in the old West German law. Additionally, there would be further child support to allow women to have kids (though this support would be less than East Germans had received under socialism).

The rhetoric of the parliamentary compromise was 'help, not punishment', saying that counseling and support would be a superior means to punishment in preventing abortion. It was thought this would enable the law to pass constitutional muster, as the dignity of unborn human life might be upheld through alternate means. Some East German feminists attempted, without success, to

since doctors made the determination about whether an indication was present, its application varied in different areas of West Germany. 
push an alternative discourse, denying that abortion need be seen by society as about protection of life at all. ${ }^{6}$ Many West German feminists pushed the compromise because they thought that any improvement would be better than nothing (Ferree/Maleck-Lewy 2000, 100).

Whatever claim the 1992 act has to being called the result of a democratic negotiation cannot be invoked by Zanetti. This is because when Zanetti talks about moral compromise on abortion, she is not talking about this parliamentary compromise. The 1992 act never went into effect, as it was declared unconstitutional by the German Federal Constitutional Court in May 1993 (101). The court said that the Act impermissibly declared that that abortion was "not illegal" (Werner 1996, 593). ${ }^{7}$ The objective value of life required that the dignity of all life be upheld, and the Court said this entailed that abortion must generally be considered a felony. ${ }^{8}$ Still, the court said abortion could still be exempt from punishment in the first trimester if a woman underwent mandatory counseling orientated toward preserving life. What Zanetti is discussing is the substance of a decision reached by a court (or the 1995 law passed in accord with the court's decision). This questions the democratic credentials of her central case and calls into question whether this is an example of a moral compromise, in the sense of acting out of what is acceptable to others.

This can be shown by asking why the court felt the need to move from the parliamentary compromise (where abortion was not unlawful in the first trimester if women went through counselling) to a solution that was similar, except for the following. The court said that the counselling could not be neutral (as the 1992 Act might be interpreted to allow), but had to be explicitly orientated towards protecting life. It was up to the woman to ultimately decide, in the sense that she was exempted from punishment. Nonetheless, the action must be considered illegal. ${ }^{9}$ One of the Court's main concerns seemed to be expressive: abortion is not to be taken as acceptable. In other words, disagreement from a strongly liberal or feminist standpoint is explicitly ruled to be out of order. The objective value of life must be upheld. The basis of tolerance is most definitely not its acceptability to these others. If anything it is the opposite.

I question whether Zanetti adequately distinguishes between two types of moral reasons which might be present in a moral compromise. The first type of reason grounds one's acceptance of second best solutions in terms of what others can accept. Zanetti's article begins by highlighting this type of moral reason. ${ }^{10}$ Above I criticized reliance on this type of reason in Zanetti's abortion case.

The second type of moral reason is not essentially concerned with the disagreement of others. The prime example of this second type is consequentialist considerations. Zanetti speaks about the second type of reason when discussing

\footnotetext{
${ }^{6}$ One East German feminist argued in parliament that a woman might see a fetus as "a parasitical mass of cells" (Ferree/Maleck-Lewy 2000, 100).

${ }^{7}$ Since Zanetti refers to the 'illegal-but-exempt-from punishment' solution, she cannot be referring to the parliamentary compromise.

8 Absent certain situations such as incest, genetic deformity, and rape.

9 Additionally, the court banned public funding of most abortions.

10 Zanetti speaks of this type at the beginning of the article, and it appears as if this might be the only type (423).
} 
why a conservative might agree to the illegal-yet-punishment-exempt compromise. He or she might be concerned about abortion tourism or back-alley abortions. He or she might see counselling as a way to save unborn life by convincing women they should not have an abortion; this counselling requires exemption from punishment. Nonetheless, perhaps this can be said to be a compromise, done with regret. If the conservative could find good ways to stop women from seeking illegal or foreign abortions, he or she might do so.

Yet in her discussion of abortion, and even when discussing consequentialist reasoning, Zanetti speaks as if this illegal-yet-punishment-exempt solution is a moral compromise between two parties: the liberal and the conservative. The liberal, says Zanetti, who sees abortion as a private matter up to the woman "must, in this sense, concede" on the issue of the time limit and accept obligatory consulting aimed at preserving life. The conservative must "depart from his categorical prohibition on abortion" (427).

However, the conservative who concedes to the more permissive abortion law on consequentialist grounds (the second type of moral reason) need not and probably does not do so "on the grounds that it would be acceptable to others involved" (the first type of moral reason) (423). The conservative may be compromising, and compromising for moral reasons, but he or she may not be compromising with anyone on the grounds that the compromise is acceptable to the others.

The conservative may have a reason to not punish all abortions, regardless of whether anyone disagrees with him in principle. It could be the case that everyone in the society is a conservative in principle, and all think abortion is murder. After all, plenty of people do acts they think wrong, from weakness of will or because they act on non-moral motives.

What reasons does the liberal have? Why would the liberal not jump to revise this settlement as soon as they could? At least the conservative may have consequentialist reasons. Indeed, East German feminists saw the parliamentary compromise as worse than the abortion law that existed previously in East Germany (Ferree/Maleck-Lewy 2000). Zanetti might answer that the liberal (and the conservative) both can have reasons based on respect for democratic procedure, but as I have mentioned, this seems doubtful in this case given that this was imposed by the court as a reflection of an objective hierarchy of values.

The conservative may simply have a tolerance based not on respect for the opinion of others, but a permissive type of tolerance, where it is seen as too disruptive to social order for the majority to enforce the correct conception. ${ }^{11}$

The tolerance here seems to be one-sided and non-reciprocal. The conservative may abide by the 'compromise', but not because they respect the moral reasoning of others. Rather, the conservative might judge that toleration would bring less harm than would an attempt to impose values. Meanwhile, the liberal may simply tell herself that this is the best she can get now. But this is not the attitude of moral compromise. The liberal may renew her fight when she can. The conservative might not renew the fight once the balance of power shifts, but only because of a belief in the harm caused by state action given the frailty of

11 On the permissive versus respect conception of tolerance, see Forst 2004, 315-316. 
human nature. His or her reasons need not involve respecting that other human beings reason differently. If this can be called moral compromise, it does not quite seem to be the type of compromise described by Zanetti.

\section{Bibliography}

Ferree, M. M./E. Maleck-Lewy (2000), Talking about Women and Wombs: The Discourse of Abortion and Reproductive Rights in the G. D. R. During and After the Wende, in: Kligman, G./S. Gal (eds.), Reproducing Gender: Politics, Publics, and Everyday Life After Socialism, Princeton, 92-117

Forst, R. (2004), The Limits of Toleration, in: Constellations 11(3), 312-325

Locke, J. (1988), Two Treatises of Government, ed. Peter Laslett, Cambridge

Simmons, A. J. (2001), Justification and Legitimacy: Essays on Rights and Obligations, Cambridge

Stemmer, P. (2004), Die Rechtfertigung moralischer Normen, in: Zeitschrift für philosophische Forschung 58(4), 483-504

Stilz, A. (2009), Liberal Loyalty: Freedom, Obligation, and the State, Princeton

Waldron, J. (1996), Kant's Legal Positivism, in: Harvard Law Review 109(7), 15351566

Werner, U. (1996), The Convergence of Abortion Regulation in Germany and the United States: A Critique of Glendon's Rights Talk Thesis, in: Loyola of Los Angeles International and Comparative Law Journal 18(3), 571-602

Zanetti, V. (2011), Justice, Peace and Compromise, in: Analyse $\& 3$ Kritik 33(2), 423439 